\title{
GAMBARAN TINGKAT KECEMASAN PASIEN PRE OPERASI DI RSU MAYJEN H.A THALIB KERINCI
}

\author{
Azma Ulia \\ Akademi keperawatan Bina Insani Sakti Sungai Penuh \\ Email Koresponensi: azmaulia6@gmail.com
}

Disubmit: 24 Januari 2022 Diterima: 27 Januari 2022 Diterbitkan: 02 Februari 2022 DOI: https://doi.org/10.33024/mnj.v5i2.5917

\section{ABSTRACT: OVERVIEW OF PREOPERATIVE PATIENT'S ANXIETY LEVEL AT MAJOR GENERAL H.A THALIB KERINCI HOSPITAL}

Introduction: Pre surgery is the time before surgery to prepare the patient for surgery both physically and psychologically. Patients before surgery will experience anxiety. Anxiety is an emotion and subjective experience of a person associated with feelings of uncertainty and powerlessness such as fear and worry.

Purpose: This study aims to determine the description of anxiety level of preoperative patients at RSJ Major General H.A Thalib Kerinci Year 2021. This type of research is quantitative research with descriptive research design. The population in this study from January to February 2021 as many as 518 patients and the sample in this study as many as 84 patients. The sampling technique uses accidental sampling. The data were analyzed univariat. The measuring tool used is the HARS (Hamilton Anxiety Rating Scale) questionnaire to measure preoperative patient's anxiety level.

Result: This research was conducted at Operation Room of Major General Hospital HA Thalib Kerinci for 1 month. The result showed that the number of respondents with mild anxiety 39 people $(46,4 \%)$, moderate anxiety 40 people $(47,6 \%)$, severe anxiety 5 people (6\%), no one experiencing panic anxiety and no one is not anxious.

Conclution: This study illustrates that most of the preoperative patients at Major General H.A Thalib Kerinci Hospital are in good psychological condition to face the surgery.

Keywords: Anxiety level, pre operation, Hospital

\section{INTISARI: GAMBARAN TINGKAT KECEMASAN PASIEN PRE OPERASI DI RSU MAYJEN H.A THALIB KERINCI}

Latar belakang : Pre operasi merupakan waktu sebelum dilakukan operasi untuk menyiapkan pasien untuk operasi baik secara fisik maupun psikologis. Pasien sebelum dilakukan operasi akan mengalami kecemasan. Kecemasan adalah sebuah emosi dan pengalaman subjektif dari seseorang yang berkaitan dengan perasaan yang tidak pasti dan tidak berdaya seperti rasa takut dan khawatir. Penelitian ini bertujuan untuk mengetahui gambaran tingkat kecemasan pasien pre operasi di RSU Mayjen H.A Thalib Kerinci Tahun 2021. 
Metode penelitian :Jenis penelitian ini adalah penelitian kuantitatif dengan desain penelitian deskriptif. Populasi pada penelitian ini dari Januari- Februari 2021 sebanyak 518 pasien dan sampel pada penelitian ini sebanyak 84 pasien. Teknik pengambilan sampel menggunakan accidental sampling. Adapun data dianalisa secara univariat. Alat ukur yang digunakan adalah kuesioner HARS (Hamilton Anxiety Rating Scale) untuk mengukur tingkat kecemasan pasien pre operasi. Penelitian ini dilakukan di Ruang operasi RSU Mayjen H.A Thalib Kerinci selama 1 bulan dari tanggal 15 Februari sampai 15 Maret 2021.

Hasil: Hasil penelitian menunjukkan bahwa jumlah responden dengan kecemasan ringan 39 orang $(46,4 \%)$, kecemasan sedang 40 orang $(47,6 \%)$, kecemasan berat 5 orang $(6 \%)$, tidak ada yang mengalami kecemasan panik dan tidak ada yang tidak cemas.

Kesimpulan: Penelitian ini menggambarkan bahwa sebagian besar pasien pre operasi di RSU Mayjen H.A Thalib Kerinci berada dalam kondisi psikologis yang cukup baik untuk menghadapi operasi.

Kata Kunci: Tingkat kecemasan, pre operasi, rumah sakit

\section{PENDAHULUAN}

Kesehatan adalah keadaan sehat, baik secara fisik, mental, spritual maupun sosial yang memungkinkan setiap orang untuk hidup produktif secara sosial dan ekonomis (Undang-Undang Kesehatan RI 36 Tahun 2009). Pembangunan kesehatan diselenggarakan dengan memberikan prioritas upaya peningkatan kesehatan, pencegahan penyakit dengan tidak mengabaikan upaya penyembuhan dan pemulihan kesehatan, salah satunya adalah tindakan operasi (Kemenkes RI, 2012).

Operasi adalah semua
tindakan pengobatan yang
menggunakan cara invasif dengan
membuka atau menampilkan bagian
tubuh yang akan ditangani. Pembukaan tubuh ini umumnya dilakukan dengan membuat sayatan. Setelah bagian yang akan ditangani ditampilkan dilakukan tindakan perbaikan yang akan diakhiri dengan penutupan dan penjahitan luka (Syamsuhidajat, 2008).

Menurut WHO (World Health Organization) dalam Sartika (2013) jumlah pasien operasi di Dunia mencapai 148 juta pasien. Menurut
Raihana (2011) di Amerika Serikat, pasien operasi berjumlah 27 juta pasien. Menurut IPDS (2012) di Inggris, pasien operasi berjumlah 10$20 \%$ dari seluruh pasien. Tindakan operasi di Indonesia pada tahun 2012 mencapai 1,2 juta jiwa (WHO dalam Sartika, 2013). Berdasarkan Data Tabulasi Nasional Departemen Kesehatan Republik Indonesia Tahun 2009, tindakan bedah menempati ururan ke-11 dari 50 pertama penanganan pola penyakit di rumah sakit se Indonesia (DEPKES RI, 2009). Di Provinsi Jambi khususnya RSUD Raden Mattaher Jambi Tahun 2013 salah satunya pasien opersi fraktur berjumlah 301 orang (Bejo, 2014).

Jumlah pasien operasi di Kabupaten Kerinci dan Kota Sungai Penuh khususnya di RSU Mayjen H.A Thalib Kerinci pada tahun 2019 sebanyak 1085 orang, tahun 2020 sebanyak 1347 orang, dan tahun 2021 pada Januari 93 orang, Februari 70 orang, Maret 121 orang dan April 92 orang (Ruang Operasi RSU Mayjen H.A Thalib Kerinci 2021).

Berdasarkan hasil penelitian yang dilakukan oleh Bolla Ibrahim (2008) tentang gambaran tingkat kecemasan pada klien pra bedah 
mayor di Ruang Rawat Inap Medikal Bedah Gedung D Lantai 3 RSU Cibabat Cimahi dari 30 responden menunjukkan bahwa yang mengalami kecemasan ringan 1 orang $(3,3 \%)$, kecemasan sedang 2 orang $(6,7 \%)$, kecemasan berat 19 orang $(63,3 \%)$, dan kecemasan panik 8 orang $(26,7 \%)$.

Menurut penelitian Anna Rohmawati (2011) tentang hubungan pemberian informed consent dengan tingkat kecemasan pada pasien pre operasi di Instalasi Rawat Inap RSUD Kajen Kabupaten Pekalongan. Dari 32 responden tingkat kecemasan sebelum diberikan informed consent menunjukkan bahwa yang mengalami kecemasan ringan 15 orang $(62,5 \%)$, kecemasan sedang 16 orang $(33,3 \%)$, dan kecemasan berat 1 orang $(4,2 \%)$.

Berdasarkan penelitian yang dilakukan oleh Pomarida Simbolon (2015) tentang pengaruh terapi musik terhadap tingkat kecemasan pada pasien preoperasi di Ruang Rawat Bedah RS Santa Elisabeth Medan menunjukkan bahwa dari 20 responden sebelum dilakukan terapi musik, yang mengalami kecemasan sedang sebanyak 7 orang ( $35 \%$ ), dan kecemasan berat sebanyak 13 orang (65\%).

Berdasarkan survey awal yang dilakukan peneliti pada 10 Februari 2020 kepada 10 orang responden didapatkan bahwa 6 orang yang mengalami kecemasan sedang, 3 orang yang mengalami kecemasan ringan, dan 1 orang yang tidak cemas.

Berdasarkan uraian diatas maka peneliti tertarik untuk meneliti tentang

"Gambaran tingkat kecemasan pasien pre operasi di RSU Mayjen H.A Thalib Kerinci" Sehingga dapat membantu perawat menggurangi rasa cemas pasien pre operasi.

\section{TINJAUAN PUSTAKA}

Cemas (ansietas) adalah perasaan yang tidak menyenangkan tidak menentu dari individu dimana penyebabnya tidak pasti/tidak ada objek yang nyata (Rasmun, 2004). Cemas (ansietas) adalah sebuah emosi dan pengalaman subjektif dari seseorang (Farida Kusumawati dan Yudi Hartono, 2012).

Menurut Videbeck (2008), respons dari ansietas ringan adalah respons fisik yaitu ketegangan otot ringan, sadar akan lingkungan, rileks atau sedikit gelisah, penuh perhatian dan rajin, adapun respon kognitif yaitu lapang persepsi luas, terlihat tenang, percaya diri, perasaan gagal sedikit, waspada dan memperhatikan banyak hal, mempertimbangkan informasi dan tingkat pembelajaran optimal, sedangkan respons emosional yaitu perilaku otomatis, sedikit tidak sadar, aktivitas menyendiri, terstimulasi, dan tenang. Respons dari ansietas sedang adalah respon fisik yaitu ketegangan otot sedang, tanda-tanda vital meningkat, pupil dilatasi, mulai berkeringat, sering mondar-mandir, memukul tangan, suara berubah : bergetar, nada suara tinggi, kewaspadaan dan ketegangan menigkat dan Sering berkemih, sakit kepala, pola tidur berubah, nyeri punggung, adapun respons kognitif yaitu lapang persepsi menurun, tidak perhatian secara selektif, fokus terhadap stimulus meningkat, rentang perhatian menurun, penyelesaian masalah menurun dan pembelajaran terjadi dengan memfokuskan pada hal yang penting, sedangkan respons emosional yaitu tidak nyaman, mudah tersinggung, kepercayaan diri goyah. Respons dari ansietas berat adalah respons fisik yaitu ketegangan otot berat, hiperventilasi, kontak mata buruk, pengeluaran keringat meningkat, bicara cepat, nada suara tinggi, tindakan tanpa tujuan dan 
serampangan, rahang menegang, mengertakan gigi, mondar-mandir, berteriak dan meremas tangan, gemetar, adapun respons kognitif yaitu lapang persepsi terbatas, proses berpikir terpecah-pecah, sulit berpikir, penyelesaian masalah buruk, tidak mampu mempertimbangkan informasi, hanya memperhatikan ancaman, preokupasi dengan pikiran sendiri dan egosentris, sedangkan respons emosional yaitu sangat cemas, agitasi, takut, bingung, merasa tidak adekuat.

\section{METODE PENELITIAN}

Jenis penelitian ini adalah penelitian kuantitatif dengan desain penelitian deskriptif yang bertujuan untuk mendeskripsikan (memaparkan) peristiwa-peristiwa urgen yang terjadi pada masa kini. Dalam hal ini peneliti ingin menggambarkan tingkat kecemasan pasien pre operasi di RSU Mayjen H.A Thalib Kerinci

\section{HASIL PENELITIAN}

Analisis Univariat

Tabel 1. Distribusi Frekuensi Responden Berdasarkan Tingkat Kecemasan Pasien Pre Operasi di Ruang Operasi RSU Mayjen H.A Thalib $(n=84)$

\begin{tabular}{lcc}
\hline Tingkat kecemasan & F & $\%$ \\
\hline Cemas ringan & 39 & 46,4 \\
Cemas sedang & 40 & 47,6 \\
Cemas berat & 5 & 6 \\
Panik & 0 & 0 \\
\hline Total & 84 & 100 \\
\hline
\end{tabular}

Dari tabel 1. didapatkan bahwa hampir setengah responden

\section{PEMBAHASAN}

Hasil penelitian pada tabel 1 menunjukkan bahwa lebih dari separoh responden yaitu 40 orang $(47,6 \%)$ memiliki tingkat kecemasan sedang, kecemasan ringan 39 orang $(46,4 \%)$, kecemasan berat 5 orang $(6$ $\%$ ), di Ruang OK (operasi) RSU Mayjen H.A Thalib Kerinci. Kecemasan merupakan keadaan perasaan afektif yang tidak menyenangkan yang disertai dengan sensasi fisik yang memperingatkan orang terhadap bahaya yang akan datang (Titik Lestari, 2015).

Dari 84 responden 39 orang $(46,4 \%)$ mengalami kecemasan mengalami kecemasan sedang yaitu 40 orang $(47,6 \%)$.

ringan. Hal ini sesuai dengan teori yang dikemukakan oleh Stuart dan Sudeen (2007) bahwa kecemasan ringan berhubungan dengan ketegangan dalam kehidupan seharihari dan menyebabkan seseorang menjadi waspada dan meningkatkan lahan persepsinya. Ansietas atau kecemasan dapat memotivasi belajar dan menghasilkan pertumbuhan dan kreativitas. Menurut Videbeck (2008), respons dari ansietas ringan adalah respons fisik yaitu ketegangan otot ringan, sadar akan lingkungan, rileks atau sedikit gelisah, penuh perhatian dan rajin, adapun respon kognitif yaitu 
lapang persepsi luas, terlihat tenang, percaya diri, perasaan gagal sedikit, waspada dan memperhatikan banyak hal, mempertimbangkan informasi dan tingkat pembelajaran optimal, sedangkan respons emosional yaitu perilaku otomatis, sedikit tidak sadar, aktivitas menyendiri, terstimulasi, dan tenang.

Dari 84 responden 40 orang $(47,6 \%)$ mengalami kecemasan sedang. Hal ini sesuai dengan teori yang dikemukan oleh Stuart dan Sudeen (2007) bahwa Ansietas atau kecemasan sedang memungkinkan seseorang untuk memusatkan pada hal yang penting dan mengesampingkan yang lain. Sehingga seseorang mengalami perhatian yang selektif namun dapat melakukan sesuatu yang lebih terarah. Menurut Videbeck (2008), respons dari ansietas sedang adalah respon fisik yaitu ketegangan otot sedang, tanda-tanda vital meningkat, pupil dilatasi, mulai berkeringat, sering mondar-mandir, memukul tangan, suara berubah : bergetar, nada suara tinggi, kewaspadaan dan ketegangan menigkat dan Sering berkemih, sakit kepala, pola tidur berubah, nyeri punggung, adapun respons kognitif yaitu lapang persepsi menurun, tidak perhatian secara selektif, fokus terhadap stimulus meningkat, rentang perhatian menurun, penyelesaian masalah menurun dan pembelajaran terjadi dengan memfokuskan pada hal yang penting, sedangkan respons emosional yaitu tidak nyaman, mudah tersinggung, kepercayaan diri goyah.

Dari 84 responden 5 orang (6\%) mengalami kecemasan berat. Hal ini sesuai dengan teori yang dikemukan oleh Stuart dan Sudeen (2007) bahwa Ansietas atau kecemasan berat sangat mengurangi lahan persepsi seseorang. Seseorang cenderung untuk memusatkan pada sesuatu yang terinci dan spesifik dan tidak dapat berpikir tentang hal lain. semua perilaku ditujukan untuk mengurangi ketegangan. Orang tersebut memerlukan banyak pengarahan untuk dapat memusatkan pada suatu area lain. Menurut Videbeck (2008), respons dari ansietas berat adalah respons fisik yaitu ketegangan otot berat, hiperventilasi, kontak mata buruk, pengeluaran keringat meningkat, bicara cepat, nada suara tinggi, tindakan tanpa tujuan dan serampangan, rahang menegang, mengertakan gigi, mondar-mandir, berteriak dan meremas tangan, gemetar, adapun respons kognitif yaitu lapang persepsi terbatas, proses berpikir terpecah-pecah, sulit berpikir, penyelesaian masalah buruk, tidak mampu mempertimbangkan informasi, hanya memperhatikan ancaman, preokupasi dengan pikiran sendiri dan egosentris, sedangkan respons emosional yaitu sangat cemas, agitasi, takut, bingung, merasa tidak adekuat.

Pasien pre operatif mengalami perasaan cemas dan ketegangan yang ditandai dengan rasa cemas, takut, tegang, lesu, tidak dapat istirahat dengan tenang. Gejala kecemasan ini dialami oleh pasien pria maupun wanita. Bagi hampir semua pasien, pembedahan merupakan sebuah tindakan medis yang sangat berat karena harus berhadapan dengan meja dan pisau operasi. Pasien tidak mempunyai pengalaman terhadap hal-hal yang akan dihadapi saat pembedahan, seperti anestesi, nyeri, perubahan bentuk dan ketidakmampuan mobilisasi post operasi. Kecemasan adalah suatu respon terhadap situasi tertentu yang mengancam dan juga hal yang normal terjadi menyertai perkembangan, perubahan, pengalaman baru atau yang belum pernah dilakukan, serta dalam 
menentukan identitas diri dan arti hidup (Kaplan dan Sadock, 2010). Penelitian ini sejalan dengan penelitian yang dilakukan oleh Yuli Widyastuti (2015) tentang gambaran kecemasan pada pasien pre operasi fraktur femur di RS Ortopedi Prof.Dr.R.Soeharso Surakarta menyatakan bahwa dari 32 responden yang memiliki tingkat kecemasan ringan 6 orang $(18,75 \%)$, kecemasan sedang 21 orang $(65,62$ $\%)$, kecemasan berat 5 orang $(15,63$ $\%)$ tidak ada yang mengalami kecemasan panik dan tidak ada yang tidak cemas.

Penelitian ini menggambarkan bahwa sebagian besar pasien pre operasi di RSU Mayjen H.A Thalib Kerinci berada dalam kondisi psikologis yang cukup baik berdasarkan Skala HARS untuk menghadapi operasi yaitu tingkat kecemasan yang dialami adalah kecemasan sedang.

\section{KESIMPULAN DAN SARAN}

Berdasarkan hasil penelitian yang telah dilakukan mengenai gambaran tingkat kecemasan pasien pre operasi di Ruang Operasi RSU Mayjen H.A Thalib Kerinci Tahun 2020, dengan total sampel sebanyak 84 orang, maka dapat diambil kesimpulan bahwa yang mengalami kecemasan ringan 39 orang, kecemasan sedang 40 orang, kecemasan berat 5 orang, tidak ada yang mengalami kecemasan panik dan tidak ada yang tidak cemas. Sehingga RSU Mayjen H.A Thalib Kerinci memperbaiki kualitas pelayanan khususnya asuhan kepperwatan pasien pre operasi Diharapkan kepada RSU Mayjen H.A Thalib Kerinci selaku institusi terkait dan tenaga kesehatan di RSU Mayjen H.A Thalib Kerinci untuk mempertahankan Standard Operating Procedure (SOP) yang telah dilakukan pada pasien pre operasi. Serta perawat harus mengisi asuhan keperawatan pre operasi dan melakukan penatalaksanaan kecemasan untuk mengurangi kecemasan yang ada seperti komunikasi terapeutik.

\section{DAFTAR PUSTAKA}

Anna Rohmawati. (2011). Hubungan pemberian informed consent dengan tingkat kecemasan pada pasien pre operasi di Instalasi Rawat Inap RSUD Kajen Kabupaten Pekalongan. Jurnal

Akbar dkk. (2014). Hubungan antara tingkat kecemasan pre-operasi dengan derajat nyeri pada pasien post sectio caesarea di Rumah Sakit Muhammadiyah Palembang Tahun 2014. Jurnal

A.Aziz Alimul H. (2006). Pengantar kebutuhan dasar manusia aplikasi konsep dan proses keperawatan. Jakarta: Salemba Medika

A.Aziz Alimul H. (2007). Metode penelitian keperawatan dan teknik analisis data. Jakarta: Salemba Medika

Eddy. (2006). Panduan bagi manajer pimpinan

perusahaan/organisasi serta mahasiwa atau peneliti. Jakarta: Letmition

Fadilah Anik Arbani. (2015). Hubungan komunikasi terapeutik dengan tingkat kecemasan pasien pre operasi di RS PKU Muhammadiyah Sukoharjo. Jurnal

Farida \& Yudi. (2012). Buku ajar keperawatan jiwa. Jakarta: Salemba Medika

Fitri, dkk. (2014). Keterampilan dasar praktik klinik. Yogyakarta: Nuha Medika

Harold I.Kaplan \& Benjamin J.Sadock. (2002). IImu kedokteran jiwa darurat. 
Wicaksana M. Roan. Jakarta: EGC

Ibrahim N. Bolla. (2008). Gambaran tingkat kecemasan pada klien pra bedah mayor di Ruang Rawat Inap Medikal Gedung D Lantai 3 RSU Cibabat Cimahi. Jurnal

I Ketut Swarjana. (2015). Statistik kesehatan. Yogyakarta: Anim

Kemenkes RI. (2012). Buku panduan pelatihan kader kesehatan gigi dan mulut dimasyarakat. Jurnal

Maria. (2012). Perbedaan tingkat kecemasan pada pasien pre operasi dengan general anestesi sebelum dan sesudah diberikan relaksasi otot progresif di RS Panti Wilasa Citarum Semarang. Semarang: Jurnal

Mary, dkk. (2007). Keperawatan medikal bedah demystified. Yogyakarta: Rapha

Notoatmodjo. (2010). Metodologi penelitian kesehatan. Jakarta: Rineka Cipta

Nursalam. (2003). Konsep \& penerapan metodologi penelitian ilmu keperawatan pedoman skripsi, tesis, dan instrumen penelitian keperawatan. Jakarta: Salemba Medika

Presiden RI. (2009). Undang-undang Republik Indonesia nomor 36 tahun 2009 tentang kesehatan. Jakarta

Pomarida Simbolon. (2015). Pengaruh terapi musik terhadap tingkat kecemasan pada pasien pre operasi di Ruang Rawat Bedah RS Santa Elisabeth Medan. Jurnal

Rasmun. (2004). Stres, koping,dan adaptasi teori dan pohon masalah keperawatan. Jakarta: Segug Seto

Ruang Operasi. (2015). Data pasien operasi di RSU Mayjen H.A Thalib Kerinci. Sungai Penuh
Sartika. (2013). Hubungan antara karakteristik demografi dengan pengetahuan mobilisasi dini pada pasien post operasi laparatomi di RS PKU Muhammadiyah Bantul. Jurnal

Stuart \& Sudeen. (2007). Buku saku keperawatan jiwa. Edisi 3. Jakarta: Penerbit Buku Kedokteran EGC

Syamsuhidayat. (2008). Perbedaan tingkat nyeri pada pasien pasca operasi mayor yang mendapatkan teknik relaksasi pernafasan dengan yang tidak mendapat teknik relaksasi pernafasan di Bangsal Bedah RSUD Cilacap. Jurnal

Titik Lestari. (2015). Kumpulan teori untuk kajian pustaka penelitian

kesehatan.Yogyakarta: Nuha Medika

V.Wiratna Sujarweni. (2014). Metodologi penelitian keperawatan. Yogyakarta : Gava Media

Videbeck. (2008). Keperawatankesehatan jiwa.

Perbedaan tingkat kecemasan antara pasien laki-laki dan perempuan pada pre operasi laparatomi di RSUP.Prof.Dr.R.D. Kandou Manado. Jurnal

Yuli Widyastuti. (2015). Gambaran kecemasan pada pasien pre operasi fraktur di RS Ortopedi Prof.Dr.R.Soeharso Surakarta. Jurnal. 